\title{
EVALUASI PENERAPAN SISTEM AKUNTANSI PENGELUARAN KAS ATAS UANG PERSEDIAAN (UP) PADA DINAS SOSIAL KOTA MANADO
}

\author{
Velasco Wongkar $^{1}$, Sifrid S. Pangemanan ${ }^{2}$, Heince R.N. Wokas ${ }^{3}$ \\ ${ }^{1,2,3}$ Jurusan Akuntansi, Fakultas Ekonomi Dan Bisnis, Universitas Sam Ratulangi Manado, Jln. Kampus Bahu, \\ Manado 95115, Indonesia \\ E-mail : veewong31@yahoo.com
}

\begin{abstract}
Efforts by local governments to regulate and manage finances in their own regions in optimizing the capacity of income in each region to improve regional development. This study aims to understand the application of cash accounting system for the Money Supply (UP) at Manado City Social Office. The method used is descriptive quantitative. The results of this study explain the implementation of cash accounting system of cash on inventory (UP) in Manado City Manado has been done in accordance with the theory of accounting system cash disbursement. It is expected that the training in the field of accounting for performance can run well.
\end{abstract}

Keywords: Accounting system cash expenditure, inventory money, implementation effectivenes

\section{PENDAHULUAN}

Seiring dengan peranan pemerintah daerah yang mengelola keuangan daerahnya sendiri sebagai upaya untuk mengoptimalkan potensi pendapatan pada tiap-tiap daerah guna meningkatkan perkembangan daerah tersebut, pendapatan pada tiap-tiap daerah tersebut harus maksimal. Seperti ditegaskan dalam UU No. 32 Tahunn 2004 bahwa otonomi daerah menggunakan prinsip otonomi seluas-luasnya dalam arti daerah diberikan kewenangan mengurus dan mengatur semua urusan pemerintahan di luar urusan pemerintah pusat yang ditetapkan dalam undang-undang tersebut. Oleh sebab itu, penyelenggaraan otonomi daerah harus selalu berorientasi pada peningkatan kesejahteraan masyarakat dengan selalu memperhatikan kepentingan dan aspirasi yang tumbuh dalam masyarakat. Untuk itu, otonomi daerah diharapkan dapat menciptakan efisiensi dan efektivitas pengelolaan sumber daya daerah, meningkatkan kualitas pelayanan umum dan kesejahteraan masyarakat, dam membudayakan dan menciptakan ruang bagi masyarakat untuk ikut berpartisipasi dalam proses pembangunan.

Agar terselenggaranya penyusunan laporan keuangan yang memenuhi asas tertib, transparansi, akuntabilitas, konsistensi, komparabilitas, akurat, dapat dipercaya dan mudah dimengerti, perlu disusun system dan prosedur akuntansi dalam pengelolaan Anggaran Pendapatan dan Belanja Daerah (APBD).

Anggaran Pendapatan dan Belanja Daerah (APBD) merupakan kebijaksanaan keuangan tahunan Pemerintah Daerah yang disusun berdasarkan ketentuan perundang-undangan yang berlaku, serta berbagai pertimbangan lainnya dengan maksud agar penyusunan, pemantauan, pengendalian dan evaluasi APBD mudah dilakukan.

APBD adalah Anggaran Pendapatan dan Belanja suatu daerah untuk satu tahun berjalan (1 periode) yang ditetapkan dengan Peraturan Daerah (Perda). APBD disusun oleh Badan Eksekutif (Pemerintah Provinsi) dan Legislatif (DPRD). Salah satu tujuan dibuat anggaran adalah untuk membiayai seluruh belanja rutin pegawai dan kegiatan publik dalam rangka meningkatkan kesejahteraan rakyat. Selanjutnya tahap pelaksanaan APBD adalah proses pelaksanaan pembiayaan pembangunan yang dilakukan oleh Pemerintah Provinsi ini 
kemudian selama tahun anggaran berjalan. Setelah tahap pelaksanaan ini kemudian dilanjutkan dengan proses pertanggungjawaban yang dilakukan oleh Gubernur kepada DPRD Provinsi untuk diberikan penilaian.

Sebagai salah satu instansi pemerintahan yang memiliki kewajiban untuk menyelenggarakan penyusunan, pelaksanaan dan pelaporan APBD, Pemerintah Daerah Provinsi Sulawesi Utara telah melaksanakan proses penganggaran sesuai dengan Peraturan Daerah (Perda) yang berlaku. Kemudian menyusun dan melaksanakan kegiatan APBD dengan mengacu pada Permendagri Nomor 57 Tahun 2007 sebagai pedoman pelaksanaan, penatausahaan hingga laporan keuangan dimana mencakup kebijakan akuntansi yang merupakan dasar yang harus dipatuhi dalam menyusun laporan keuangan.

Dinas Sosial Kota Manado sebagai salah satu Satuan Kerja Perangkat Daerah di lingkup Pemerintah Kota Manado dalam kegiatannya menggunakan dana APBN dan APBD. Dana APBD yang tertuang dalam DPA diupayakan semaksimal mungkin untuk pencapaian realisasinya disesuaikan dengan anggaran kas dan target yang ditentukan.

Dalam proses penyerapan dana APBD, system dan prosedur akuntansi pengeluaran kas yang digunakan terdiri dari 4 sub system yaitu sub system akuntansi pengeluaran kas pembebanan uang persediaan (UP), sub system akuntansi pengeluaran kas pembebanan ganti uang persediaan (GU), sub system akuntansi pengeluaran kas pembebanan tambahan uang persediaan (TU) dan sub system akuntansi pengeluaran kas pembebanan langsung (LS). Pelaksanaan realisasi anggaran dapat dijadikan acuan untuk mengetahui sejauh manakah anggaran tersebut dipergunakan. SKPD juga dituntut harus memiliki SDM (Sumber Daya Manusia) yang mampu menyusun laporan keuangan daerah yang sesuai dengan UU dan Peraturan yang berlaku agar sesuai dengan pelaksanaan realisasinya. Fenomena yang terjadi pada Dinas Sosial Kota Manado adalah terjadinya keterlambatan dalam penyerapan anggaran khususnya dalam penggantian penggunaan uang persediaan (UP) dalam bentuk Ganti Uang (GU). Dimana dalam memulai aktivitasnya, Dinas Sosial Kota Manado mendapat Uang Persediaan (UP) yang bentuk pertanggung jawabannya dalam bentuk Ganti Uang (GU).

Fenomena tersebut terjadi karena, Sub Bagian Perencanaan dan Keuangan khususnya yang menangani APBD harus mengumpulkan bukti Surat Pertanggung Jawaban (SPJ) sebelum diserahkan untuk dilaporkan. Pengumpulan bukti tersebut memerlukan waktu yang cukup lama. Selain dari pengumpulan bukti yang cukup, kemampuan sumber daya manausia belum merata, perangkat pendukung teknis sering mengalami gangguan, proses birokrasi yang panjang dan jarak antara kantor Dinas Sosial Kota Manado dengan Badan Pengelola Keuangan dan Barang Milik Daerah yang jauh menjadi penyebab terjadinya pengunduran waktu dalam proses pertanggung jawaban atas uang persediaan yang telah digunakan.

Dalam pelaksanaannya, Sistem Akuntansi Pengeluaran Kas Atas Uang Persediaan (UP) di Dinas Sosial Kota Manado berjalan sesuai dengan prosedur dan ketentuan perundangundangan yang berlaku, hanya saja waktunya tidak sesuai dengan yang diharapkan, dimana selalu terjadi keterlambatan. Terhambatnya proses realisasi Uang Persediaan (UP) dalam bentuk Ganti Uang (GU) menyebabkan terhambatnya proses pengeluaran kas dalam bentuk Tambah Uang dan Pembayaran Langsung (LS), karena pekerjaan Bendahara Pengeluaran terfokus pada SPJ Uang Persediaan dimana penggunaannya untuk pengeluaran rutin kantor.

\section{TINJAUAN PUSTAKA}

\subsection{Konsep Akuntansi}

\subsubsection{Pengertian Akuntansi}

Menurut Darsono dan Ashari (2012), Akuntansi adalah suatu seni pencatatan, penggolongan, dan peringkasan dengan cara yang informative dan diukur dalam bentuk mata uang, atas transaksi-transaksi atau kejadian-kejadian keuangan perusahaan, dan interpretasi hasilnya. Dari definisi tersebut maka catatan yang ada dalam akuntansi melipti Jurnal 
(Pencatatan), buku besar (penggolongan), neraca lajur/neraca saldo (peringkasan) dan Laporan keungan (pelaporan).

\subsubsection{Fungsi Akuntansi}

Menurut Mulyadi (2012) dari segi fungsinya :

1. Suatu aktivitas penyediaan jasa

Akuntansi memberikan informasi keuangan kepada pihak yang berkepentingan (stakeholders), untuk membantu dalam membuat keputusan ekonomik yang menyangkut perusahaan tersebut.

2. Suatu Sistem Informasi

Akuntansi melakukan pengumpulan dan pengolahan data keuangan perusahaan yang kemudian dikomunikasikan kepada stakeholders agar dapat dipakai dalam pengambilan keputusan yang menyangkut perusahaan.

\subsubsection{Akuntansi Sektor Publik}

Akuntansi sektor publik adalah sistem akuntansi yang dipakai oleh lembaga-lembaga publik sebagai salah satu alat pertanggung jawaban kepada publik. Sekarang terdapat perhatian yang makin besar terhadap praktek akuntansi yang dilakukan oleh lembagalembaga publik, baik akuntansi sektor pemerintahan maupun lembaga publik non pemerintah. Lembaga publik mendapat tuntutan dari masyarakat untuk dikelola secara transparan dan bertanggungjawab. Organisasi sektor publik menghadapi tekanan untuk lebih efisien, memperhitungkan biaya ekonomi dan biaya sosial dan memanfaatkannya bagi publik, serta dampak negatif atas aktivitas yang dilakukan.

Sektor publik adalah manajemen keuangan yang berasal dari publik sehingga menimbulkan konsekuensi untuk dipertanggung jawabkan kepada publik. Dengan demikian, pengelolaannya memerlukan keterbukaan dan akuntabilitas terhadap publik.

\subsection{Sistem Informasi Akuntansi Pengeluaran Kas}

Sistem informasi akuntansi pengeluaran kas terbagi menjadi dua bagian yaitu sistem informasi akuntansi pengeluaran kas dengan cek dan sistem dana kas kecil. Sistem informasi akuntansi pengeluaran kas dengan cek adalah pengeluaran kas dengan menggunakan cek dan pengeluaran kas dengan menggunakan cek biasanya karena jumlahnya relatif besar. Menurut Mulyadi (2012) Pengeluaran kas dengan cek memiliki kebaikan ditinjau dari pengendalian interen berikut ini :

1. Dengan digunakannya cek atas nama, pengeluaran cek akan dapat diterima oleh pihak yang namanya sesuai dengan yang ditulis pada formulir cek. Dengan demikian pengeluaran kas dengan cek menjamin diterimanya cek tersebut oleh pihak yang dimaksud oleh pihak pembayar.

2. Dilibatkannya pihak luardalam hal ini Bank, dalam pencatatan transaksi pengeluaran kas perusahaan. Dengan diadakannya cek dalam setiap pengeluaran kas perusahaan transaksi pengeluaran kas direkam juga oleh bank yang secara periodik mengirimkan rekening koran bank (bank statement) kepada perusahaan nasabahnya. Rekening koran inilah yang dapat digunakan perusahaan untuk mengecek ketelitian catatan transaksi kas perusahaan yang direkam didalam jurnal penerimaan dan pengeluaran kas.

3. Jika sistem perbankan mengembalikan cancelled check kepada check issuer, pengeluaran kas dengan cek memberikan manfaat bagi perusahaan yang mengeluarkan cek dengan dapat digunakannya cancelled check sebagai tanda terima kas dari pihak yang menerima pembayaran. Dengan digunakannya cek dalam pengeluaran kas, check issuer akan secara otomatis menerima tanda penerimaan kas dari pihak yang menerima pembayaran.

\subsubsection{Fungsi Yang Terkait}

Menurut Mulyadi (2012) fungsi-fungsi yang terkait dalam transaksi siklus pengeluaran adalah: 
a. Fungsi yang memerlukan pengeluaran kas (misalnya untuk pembelian jasa dan untuk biaya perjalanan dinas). Fungsi yang bersangkutan mengajukan permintaan cek kepada fungsi pencatatan utang. Permintaan cek ini harus mendapat persetujuan dari kepala fungsi yang bersangkutan.

b. Fungsi Pencatatan Utama

c. Fungsi Keuangan

d. Fungsi Akuntansi Biaya.

e. Fungsi Akuntansi Umum

f. Fungsi Audit Interen

\subsubsection{Catatan Yang Digunakan}

Menurut Mulyadi (2012) catatn akuntansi yang digunakan dalam sistem informasi akuntansi pengeluaran kas adalah:

a. Jurnal pengeluaran kas (Cash Disbursement Journal)

Dalam pencatatan utang account payable system, untuk mencatat transaksi pembelian yang digunakan jurnal pembelian dan untuk mencatat pengeluaran kas digunakan jurnal pengeluaran kas.

b. Register Cek (Check Register)

Dalam pencatatan utang dengan voucher payable system, transaksi untuk mencatat transaksi pembelian digunakan dua jurnal, register bukti kas keluar dan register cek. Register bukti kas keluar digunakan untuk mencatat utang yang timbul, sedangkan register cek digunakan untuk mencatat pengeluaran kas dengan cek.

\subsubsection{Dokumen-Dokumen Yang Digunakan}

Menurut Mulyadi (2012) dokumen yang digunakan dalam sistem pengeluaran kas adalah:

1. Bukti kas keluar

2. Cek

3. Permintaan cek (Check Request)

\subsubsection{Prosedur Pengeluaran Kas}

Menurut Soemarso S.R (2009) untuk dapat menghasilkan sistem pengawasan yang baik, prosedur pengeluaran uang harus memprhatikan hal sebagai berikut:

1. Semua pengeluaran dilakukan dengan cek, pengeluaran-pengeluaran dalam jumlah kecil dilakukan melalui dana kas kecil.

2. Semua pengeluaran kas harus memperoleh persetujuan dari yang berwenang terlebih dahulu.

\subsection{Konsep Pengelolaan Keuangan Daerah}

Peraturan Menteri Dalam Negeri Nomor 13 Tahun 2006 tentang Pedoman Pengelolaan Keuangan Daerah, BAB I Ketentuan Umum Bagian Pertama Pengertian Pasal 1, dalam peraturan menteri ini yang dimaksud dengan :

1. Anggaran Pendapatan dan Belanja Daerah, selanjutnya disingkat APBD adalah rencana keuangan tahunan pemerintahan daerah yang dibahas dan disetujui bersama oleh pemerintah daerah dan DPRD dan ditetapkan dengan peraturan daerah.

2. Uang Persediaan (UP) adalah uang muka kerja yang bersifat pengisian kembali (revolving) yang tidak dapat dilakukan dengan pembayaran langsung atas beban-beban pengeluaran DPA-SKPD yang dipergunakan sebagai uang persediaan untuk mendanai kegiatan.

3. Ganti Uang (GU) adalah pengganti uang persediaan yang tidak dapat dilakukan dengan pembayaran langsung yang dananya dipergunakan untuk mengganti uang persediaaan yang telah dibelanjakan. 


\subsection{Dokumen Pelaksanaan Anggaran (DPA)}

Dokumen Pelaksanaan Anggaran Satuan Kerja Perangkat Daerah (DPA-SKPD) Dinas

Sosial Kota Manado Tahun Anggaran 2014 terdiri atas Pendapatan dan Belanja.

Pendapatan $\rightarrow$ Pendapatan Asli Daerah $\rightarrow$ Retribusi Daerah

Belanja $\rightarrow$ Belanja Tidak Langsung $\rightarrow$ Belanja Pegawai

$$
\begin{aligned}
\rightarrow \text { Belanja Langsung } & \longrightarrow \text { Belanja Pegawai } \\
& \mapsto \text { Belanja Barang dan Jasa } \\
& \mapsto \text { Belanja Modal }
\end{aligned}
$$

\section{METODE PENELITIAN}

\subsection{Jenis Penelitian}

Penelitian ini menggunakan metode penelitian deskriptif kuantitatif yaitu, dalam bentuk uraian, seperti nama satuan kerja perangkat daerah, tugas pokok dan fungsi, serta visi dan misi. Adapun data yang meliputi Surat Penyediaan Dana (SPD), Surat Permintaan Pembayaran (SPP), Surat Permintaan Membayar (SPM), Penerbitan Surat Perintah Pencairan Dana (SP2D).

\subsection{Sampel dan teknik pengambilan sampel}

a. Data Primer

Data primer adalah data-data yang diperoleh dari lokasi penelitian dalam hal Satuan Kerja Perangkat Daerah (SKPD), yang meliputi data umum dan data khusus. Data umum yaitu data-data mengenai Nama Satuan Kerja Perangkat Daerah (SKPD), Struktur Organisasi, Tugas Pokok dan Fungsi serta Visi dan Misi, sedangkan data khusus yaitu data-data yang berkaitan dengan topik pembahasan sebagai bahan evaluasi dan analisase pertidokumen, catatan dan data pendukung lainnya.

b. Data Sekunder

Data sekunder adalah data yang berasal dari literature kepustakaan yang berkaitan dengan penelitian.

c. Observasi

Observasi yaitu metode pengumpulan data yang dilakukan dengan cara melakukan pengamatan terhadap aktivitas Satuan Kerja Perangkat Daerah khususnya di Sub Bagian Perencanaa ndan Keuangan.

d. Inspeksi

Inspeksi yaitu metode pengumpulan data yang dilakukan dengan melakukan pengecekan langsung terhadap system pengelolaan keuangan daerah dan dokumendokumen yang berhubungan dengan transaksi yang mengakibatkan pemakaian Uang Persediaan (UP) yang dipertanggung jawabkan dalam bentuk Ganti Uang (GU).

e. Wawancara

Wawancara adalah metode pengumpulan data yang dilakukan dengan mewawancarai staf sub bagian perencanaan dan keuangan yang terkait dengan system akuntansi terhadap transaksi-transaksi yang menggunakan uang persediaan.

f. Studi Kepustakaan

Studi Kepustakaan yaitu metode pengumpulan data dengan mengambil pedoman dari berbagai buku referensi dan peraturan pemerintah yang berhubungan dengan system akuntansi pengelolaan keuangan daerah.

\subsection{Metode analisis}

Dalam penelitianini, menggunakan metode analisis deskriptif dengan cara menguraikan, menjelaskan dan menggambarkan tentang bagaimana penerapan system akuntansi pengeluaran kas yang ada di Dinas Sosial Kota Manado. 


\section{HASIL ANALISIS DAN PEMBAHASAN}

\subsection{Gambaran Umum Objek Penelitian}

Kedudukan Dinas Sosial Kota Manado yang secara langsung dibawah Kepala Daerah dan Wakil Kepala Daerah, yang adalah instansi teknis sebagai pelaksana tugas otonomi daerah yang dipimpin oleh seorang Kepala Dinas dengan tugas pokok membantu Kepala Daerah dan Wakil Kepala Daerah dalam penyelenggaraan sebagian urusan pemerintahan dibidang sosial.

Pembentukan Dinas Sosial yang merupakan gabungan dari Dinas Sosial dan Badan Pemberdayaan Masyarakat dan Pemerintahan Kelurahan ditetapkan dalam PP No. 18 tahun 2016 tentang Perangkat Daerah dan Peraturan Daerah Kota Manado Nomor 2 Tahun 2016 tentang Dinas-dinas Kota Manado, sebagai Implementasi PP No. 41 Tahun 2007 tentang Organisasi Pemerintah Daerah dengan struktur organisasi yang berada dibawah tanggung jawab kepada Walikota.

Dinas Sosial mempunyai tugas dan kewajiban membantu Kepala Daerah untuk meningkatkan Pelayanan Kesejahteraan Sosial di Kota Manado.

Tugas dan Fungsi

Dinas Sosial Kota Manado mempunyai fungsi sebagai berikut :

1. Penyusunan Program dan kegiatan yang dapat menunjang pelayanan kepada masyarakat kota Manado.

2. Pengoordinasian pelaksanaan tugas fungsi dinas daerah dan lembaga teknis daerah.

3. Pemantauan dan evaluasi pelaksanaan kebijakan pemerintahan daerah.

4. Pembinaan administrasi di Dinas Sosial

5. Pelaksanaan tugas dan fungsi lain yang diberikan oleh Kepala Daerah sesuai dengan tugas dan fungsinya.

\subsection{Hasil Pembahasan}

Evaluasi atas sistem akuntansi dimaksudkan agar penulis dapat memahami setiap dokumen, catatan akuntansi, pihak yang terkait dan prosedur yang digunakan dalam proses Pengeluaran Kas Atas Uang Persediaan (UP) dalam bentuk Ganti Uang (GU), pada Dinas Sosial Kota Manado

Mekanisme penggunaan Uang Persediaan (UP) hanya dapat digunakan untuk pengeluaran rutin SKPD dan pengeluaran - pengeluaran pada program dan kegiatan pada pos Belanja Barang dan Jasa yang bersifat kecil dengan nominal < 10 Juta. UP (Uang Persediaan) diisi kembali dengan mekanisme Ganti Uang (GU).

Adapun pengeluaran-pengeluaran rutin SKPD Dinas Sosial Kota Manado yang tertata dalam DPA (Dokumen Pelaksanaan Anggaran) tahun 2018 terdiri atas :

A. Program Pelayanan Adminsitrasi Perkantoran

1. Kegiatan penyediaan kebutuhan administrasi umum

2. Kegiatan penyediaan kebutuhan admistrasi keuangan

3. Kegiatan penyediaan kebutuhan administrasi barang/jasa

4. Kegiatan penyediaan kebutuhan administrasi kepegawaian

5. Kegiatan pelaksanaan rapat koordinasi dan konsultasi

Berikut ini adalah evaluasi sistem pengeluaran kas atas UP dalam bentuk GU pada Dinas Sosial Kota Manado.

\subsubsection{Evaluasi Fungsi Yang Terkait}

Sistem pengeluaran kasatas Uang Persediaan (UP) dalam bentuk Ganti Uang (GU) pada Dinas Sosial Kota Manado dengan fungsi yang dilaksanakan oleh Bendahara Pengeluaranuntuk membuat surat permohonan SPD (Surat Penyediaan Dana), mempersiapkan dokumen SPP beserta lampirannya, mengajukan SPP (Surat Permintaan Pembayaran) kepada PPK-SKPD, mencatat SP2D (Surat Perintah Pencairan Dana) pada dokumen penatausahaan, menguji kebenarandan kelengkapan dokumen pertanggungjawaban, 
melakukan pencatatan bukti-bukti pembelanjaan dana dari UP/GU pada dokumen -dokumen (Buku Kas Umum, Buku Pembantu Pajak, Buku Pembantu Panjar, Buku Pembantu Pengeluaran per Objek), melakukan rekapitulasi pengeluaran dan mencatatnya dalam SPJ yang akan diserahkan ke Pengguna Anggaran (melalui PPK-SKPD) untuk disahkan.

Fungsi yang dilakukan oleh $P P K-S K P D$ bertugas untuk menguji kelengkapan dan kebenaran SPP yang diajukan Bendahara Pengeluaran beserta kelengkapannya, membuat rancangan SPM atas SPP yang telah diuji kelengkapan dan kebenarannya dan mengajukannya ke Pengguna Anggaran, menerbitkan surat penolakan SPM bila SPP yang diajukan oleh Bendahara SKPD tidak lengkap, membuat register SPM, meneliti kelengkapan dokumen pertanggungjawaban dan keabsahan bukti-bukti pengeluaran yang dilampirkan, menguji kebenaran perhitungan atas pengeluaran per rincian objek yang tercantum dalam ringkasan per rincian objek, menghitung pengenaan $\mathrm{PPN} / \mathrm{PPh}$ atas beban pengeluaran per rincian obyek, menguji kebenaran sesuai dengan SPM dan SP2D yang diterbitkan periode selanjutnya, meregister SPJ pengeluaran yang disampaikan oleh Bendahara Pengeluaran dalam buku register penerimaan SPJ pengeluaran, meregister SPJ pengeluaran yang telah disahkan oleh Pengguna Anggaran ke dalam buku register pengesahan SPJ pengeluaran dan meregister SPJ pengeluaran yang telah ditolak oleh Pengguna Anggaran ke dalam buku register penolakan SPJ Pengeluaran. Fungsi yang dilakukan oleh Pengguna Anggaran bertugas untuk mengotorisasi dan menerbitkan SPM, mengotorisasi surat penolakan SPM yang diterbitkan PPK-SKPD bila SPP yang diajukan bendahara SKPD tidak lengkap, menandatangani SPM, menyetujui atau menolak SPJ pengeluaran yang diajukan oleh Bendahara Pengeluaran. Fungsi yang dilakukan oleh BPK-BMD (Kuasa BUD, PPKD, $S K P K D)$ bertugas untukmenganalisa DPA-SKPD yang ada di database, menganalisa anggaran kas pemerintah khususnya data per SKPD, menyiapkan draft SPD, mendistribusikan SPD kepada para pengguna anggaran, melakukan otorisasi SPD, melakukan pengujian atas kebenaran dan kelengkapan SPM, mencetak SP2D, mengirimkan SP2D kepada bank, membuat dokumen-dokumen (register SP2D, register surat penolakan penerbitan SP2D dan buku kas penerimaan dan pengeluaran), mencatat SP2D pada dokumen penatausahaan.

\subsubsection{Evaluasi Dokumen Yang Digunakan}

Dokumen yang digunakan dalam sistem pengeluaran kas atas Uang Persediaan (UP) dalam bentuk Ganti Uang (GU) pada Dinas Sosial Kota Manado, sudah cukup baik dan digunakan sebagaimana mestinya. Surat Penyediaan Dana (SPD) berdasarkan permintaan dari SKPD dikeluarkan oleh PPKD selaku BUD. Surat Perintah Membayar (SPM) yang ditandatangani oleh Pengguna Anggaran sebagai persetujuan pencairan dana diverifikasi oleh PPK-SKPD dan seorang verifikator. Surat Perintah Pencairan Dana (SP2D) harus ditandatangani oleh Kuasa BUD agar dokumen memiliki kekuatan hukum yang mengikat dan langsung diserahkan ke Bank Sulut untuk di posting ke rekening yang tertera di SPM.

Dokumen yang digunakan sudah cukup baik dan sesuai dengan prosedur yang ada. Dokumen yang digunakan lebih dari 1 lembar sehingga fungsi control dapat dilakukan oleh fungsi yang berhubungan. Proses yang ada telah efektif dan sesuai dengan peraturan dan perundang-undangan yang berlaku.

\subsubsection{Evaluasi Catatan Akutansi Yang Digunakan.}

Pencatatan setiap transaksi pengeluaran kas atas Uang Persediaan (UP) dalam bentuk Ganti Uang (GU) pada Dinas Sosial Kota Manado menggunakan catatan akuntansi secara komputerisasi melalui aplikasi SIMDA (Sistem Informasi Manajemen Daerah) Keuangan versi 2.1 oleh BPKP.Dimana semua jurnal dan neraca bisa langsung dicetak.

Berdasarkan hasil penelitian dapat dikatakan bahwa catatan akuntansi telah memadai dan dapat mencegah terjadi penyimpangan, Proses yang ada telah efektif dan sesuai dengan peraturan dan perundang-undangan yang berlaku. 


\subsubsection{Evaluasi Prosedur Pengeluaran Kas atas Uang Persediaan (UP) dalam bentuk Ganti Uang (GU)}

Prosedur pengeluaran kasatas Uang Persediaan (UP) dalam bentuk Ganti Uang (GU) Dinas Sosial Kota Manado yang ada telah membentuk sistem dan sesuai dengan Flowchart yang baku, namun penerapannya sering terjadi keterlambatan pada masing-masing unit kerja. Hal ini disebabkan tidak meratanya sumber daya manusia dan beberapa perangkat pendukung teknis yang tidak bekerja dengan optimal.Setiap unit kerja memiliki SOP (Standar Operation Prosedur) sehingga apabila terdapat keterlambatan maka itu disebabkan oleh karena adanya staf yang menunda-nunda pekerjaan ataupun karena adanya masalah jaringan.Hal itulah yang mengakibatkan prosedur pengeluaran kas atas UP dalam bentuk GU pada Dinas Sosial Kota Manado berjalan lambat.Untuk itu sebaiknya setiap pihak terkait menjalankan tugas sesuai dengan tanggungjawabnya agar tidak terjadi keterlambatan dan kesalahpahaman dalam pekerjaan.

\section{KESIMPULAN DAN SARAN}

\subsection{Kesimpulan}

Pelaksanaan system akuntansi pengeluaran kas atas uang persediaan di Dinas Sosial Kota Manado telah dilakukan sesuai dengan teori system akuntansi pengeluaran kas serta aturan yang ada mencakup fungsi yang terkait, dokumen yang digunakan, catatan akuntansi yang digunakan dan jaringan prosedu rsistem akuntansi pengeluaran kas. Sistem akuntansi pengeluaran kas atas uang persediaan pada Dinas Sosial Kota Manado, sudah memiliki flowchart yang baku, namun seringkali tidak dijalankan dengan baik.

\subsection{Saran}

Dalam pelaksanaan system penatausahaan pengelolaan keuangan daerah dibutuhkan tenaga sumber daya manusia atau pegawai untuk menjalankan perangkat pendukung yang digunakan dalam system akuntansi pengeluaran kas tersebut. Sehubungan dengan aplikasi Sistem Akuntansi Pemerintah Daerah yang merupakan program tersendiri, maka dibutuhkan lebih banyak pegawai yang mengerti dengan baik dan dapat menjalankan secara benar program aplikasi tersebut.

Dalam pelaksanaan system akuntansi pengeluaran kas membutuhkan perangkat pendukung teknis yang mampu bekerja dan digunakan optimal sehingga penyusunan laporan dapat dilakukan dengan baik. Perangkat pendukung teknis merupakan unit komputer yang mampu melaksanakan perhitungan-perhitungan dengan cepat dan akurat.

Diharapkan adanya pelatihan dalam bidang akuntansi agar dalam proses kinerja dapat berjalan sesuai yang diharapkan

\section{DAFTAR PUSTAKA}

Anastasia, D \&Lilis S, 2011.Sistem Informasi Akuntansi. PenerbitAndi: Jakarta

Christien Natalia Supit. 2014, "Evaluasi Sistem Akuntansi Pengeluaran Kas atas Pencairan Kredit pada PT. Bank Bukopin, Tbk", Skripsi, Manado :STIE Eben Haezar Manado

Dunia, Firdaus A. 2012. Pengantar Akuntansi Edisi 3. Fakultas Ekonomi Universitas Indonesia; Jakarta

Fretty S. Tuerah. 2013, "Evaluasi Pelaksanaan Sistem dan Prosedur Penerimaan dan Pengeluaran Kas Dinas Kependudukan dan Pencatatan Sipil Minahasa Tenggara", Skripsi, Manado :Universitas Sam Ratulangi Manado

Harahap, SofyanSyafri. 2015. Teori Akuntansi. Penerbit PT. Raja Grafindo Persada : Jakarta Mulyadi, 2012.Sistem Akuntansi edisi 3: Salemba Empat : Jakarta

Narko 2013. Sistem Akuntansi -Yayasan Pustka Nusantara : Yogjakarta

Nordiawan, Deddi. 2016. Akuntansi Sektor Publik. Jakarta: Salemba Empat. 
Puspitawati \& Anggadini, 2011.Sistem Informasi akuntansi: Penerbit Andi Yogyakarta Prianthara, BT. 2015. Sistem Informasi Akuntansi. CV Yrama Widya: Bandung Renyowijoyo, Muindro. 2015. Akuntansi Sektor Publik: Organisasi Non Laba. Jakarta: MitraWacana Media

Umbuan V, 2012. Perancangan Sistem Informasi Akuntansi. Yogjakarta

Renyowijoyo, Muindro. 2010. Akuntansi Sektor Publik: Organisasi Non Laba. Jakarta: Mitra Wacana Media

...(2008) Peraturan Daerah Provinsi Sulawesi Utara Nomor 3 tentang Organisasidan Tata Kerja Dinas Daerah Provinsi Sulawesi Utara

...(2006) Pedoman Pengelolaan Keuangan Daerah Permendagri Nomor 13 